\title{
Effect of Job Satisfaction, Quality of Work Life, and Self Efficacy on Employee Work Productivity Case Study on PT. Bank Woori Saudara Indonesia Tbk
}

\author{
Adisah Putra Sitohang and Nur Aktif Budiono
}

\section{ABSTRACT}

\begin{abstract}
This study aims to analyze the effect of job satisfaction, quality of work life, and self-efficacy on employee work productivity (Case Study at PT Bank Woori Saudara Indonesia Tbk, Kebon Jeruk Sub-Branch). The population of this study was employees of PT Bank Woori Saudara Indonesia 1906 SubBranch of Kebon Jeruk as many as 57 employees, with a total sample of the entire population. The data analysis method used Structural Equation Model-Partial Least Square (SEM-PLS). The results of the study found that job satisfaction has a positive and significant effect on employee work productivity, quality of work life has a positive and significant effect on employee productivity, and self-efficacy has a positive and significant effect on employee productivity. It is suggested to the management of PT Bank Woori Saudara Indonesia 1906 Sub-Branch Kebon Jeruk to review the salary policy given to employees. What can be done is to apply merit pay, which is a compensation system based on employee performance.
\end{abstract}

Keywords: Employee Work Productivity, Job Satisfaction, Quality of Work Life, Self-Efficacy.

\author{
Submitted : August 06, 2021 \\ Published : September 10, 2021 \\ ISSN: 2507-1076 \\ DOI: $10.24018 /$ ejbmr.2021.6.5.1034 \\ Adisah Putra Sitohang* \\ Master of Management, Mercu Buana \\ University, Jakarta, Indonesia. \\ (e-mail: adisahsitohang2@gmail.com) \\ Nur Aktif Budiono \\ Mercu Buana University, Jakarta, \\ Indonesia. \\ (e-mail: nuraktif123@gmail.com)
}

*Corresponding Author

\section{INTRODUCTION}

The history of the development of the Indonesian economy basically started with the banking industry because the performance of the Indonesian economy dynamically depends on sources of financing from the banking sector. Where the state of the Indonesian economy is known as a bank-based economy. In this case, the role of the banking sector can be said to be a supporting facility for the development of Indonesia's economic growth.

Bank is one form of company in the service sector. Human resources are a very valuable asset for companies in the service sector because this type of company sells services. The work productivity of employees will be reflected in the services they provide to customers. If the productivity provided is not satisfactory, the customer will not do business again with the company. So, it can be seen that employee work productivity is very influential on the survival of banking companies [1].

Everyone who works expects to get satisfaction from his place of work. Basically, job satisfaction is an individual thing because each individual will have a different level of satisfaction according to the values that apply to each individual.

In addition to job satisfaction, quality of work life is a process to achieve employee perceptions of a sense of security at work, job satisfaction, and the opportunity to grow and develop according to the needs and work life plans in order to increase employee dignity and support company effectiveness. The creation of a good quality of work life is also inseparable from the high and low self-efficacy which will later affect the individual's way of acting/overcoming a situation to achieve achievement.

One way of executing the above will usually be stated in a target so that the bank can measure the extent of the company's movement. Therefore, the role of employees in achieving these targets is very important. Every Bank will always try to improve the productivity of its employees, with the hope that the Bank's goals will be achieved [2]. Employee capabilities are reflected in optimal productivity. Employee productivity is one of the capitals for the company to achieve its goals.

Banks have a very important role in the stability of the Indonesian economy. With all its activities, a bank, like a company in general, needs the support of employees who are able to provide performance for the company. For a bank, productivity relates to the ability of a bank to serve customers and issue new products according to customer needs.

One of the banks that have attention to employee productivity is PT. Bank Woori Saudara Indonesia 1906, Tbk. The Bank's increasingly good performance has resulted in awards received, one of which is the Diamond Trophy from Infobank in 2018 for performance that is considered very good.

To continue to maintain this, good employee productivity is needed so that the Bank can continue to compete in the banking industry in Indonesia. One of the things to worry about is employee productivity that has not been optimal, especially in the Kebon Jeruk sub-branch office. Based on the results of the HRD assessment, it was concluded that there was a decline in employee productivity in 3 consecutive years.

To increase productivity, employees need comfort and satisfaction at work. The results of the job satisfaction survey 
placed a number of employees who still feel dissatisfied with PT. Bank Woori Saudara Indonesia 1906, Tbk, a sub-branch of Kebon Jeruk. In addition, based on the satisfaction assessment of 57 employees, it was concluded that there were no employees who were very satisfied. This indicates a problem with job satisfaction.

\begin{tabular}{|c|c|c|}
\hline Statement & Yes & No \\
\hline $\begin{array}{l}\text { I have good work productivity because the work I do } \\
\text { is according to my abilities }\end{array}$ & 23 & 2 \\
\hline $\begin{array}{l}\text { I have good work productivity because I am satisfied } \\
\text { with the salary, I currently receive }\end{array}$ & 20 & 5 \\
\hline $\begin{array}{l}\text { I have good work productivity because } \\
\text { communication with co-workers is very good }\end{array}$ & 22 & 3 \\
\hline $\begin{array}{l}\text { I have good work productivity because the company } \\
\text { provides space for employees to express opinions }\end{array}$ & 20 & 5 \\
\hline $\begin{array}{l}\text { I have good work productivity because the company } \\
\text { includes regular job training }\end{array}$ & 10 & 15 \\
\hline $\begin{array}{l}\text { I have good work productivity because the company } \\
\text { provides scholarships to continue my formal education }\end{array}$ & 12 & 13 \\
\hline $\begin{array}{l}\text { I have good work productivity because the company } \\
\text { provides counseling services for employees }\end{array}$ & 0 & 25 \\
\hline $\begin{array}{l}\text { I have good work productivity because I understand } \\
\text { the work procedures, I get }\end{array}$ & 17 & 8 \\
\hline $\begin{array}{l}\text { I have good work productivity because I feel I can } \\
\text { complete tasks at work }\end{array}$ & 19 & 6 \\
\hline $\begin{array}{l}\text { I have good work productivity because I have } \\
\text { experience with my current job }\end{array}$ & 15 & 10 \\
\hline
\end{tabular}

As an initial illustration, a pre-survey was conducted to analyze the determinants of Work Productivity. Factors that affect employee productivity is job satisfaction. This can be seen from the $92 \%$ "Yes" response to the statement "I have good work productivity because the work is done according to ability" which shows employees are satisfied with their current job because it is in accordance with their abilities. The next factor that affects employee work productivity is the quality of work life. This can be seen from the "Yes" response of $88 \%$ to the statement "I have good work productivity because communication with coworkers is very good" which shows that communication between coworkers is able to shape the quality of work life that is getting better and has an impact on work productivity. The last factor that affects employee work productivity is self-efficacy. This can be seen from the "Yes" response of $76 \%$ to the statement "I have good work productivity because I feel I can complete tasks at work" indicating that employees' self-confidence in the work they face (self-efficacy) can be a driving factor for increasing work productivity employee.

It is hoped that this research can contribute to increasing scientific knowledge regarding the effect of Job Satisfaction, Quality of Work Life, and Self Efficacy on Employee Work Productivity. In addition, so that this research will provide recommendations for company management in increasing employee productivity to improve the company's overall performance.

\section{LITERATURE REVIEW}

Sinungan describes productivity as a concept to produce a lot of useful output from a small amount of input [3]. Meanwhile, Mathis \& Jackson mention that productivity is related to measuring the quality and quantity of employees with consideration of the company's resources [4]. Aspects of work productivity include the ability of an employee to carry out their duties depending on the skills they have and their professionalism at work. This gives them the power to complete the tasks assigned to them.

Satisfaction when working is something that is coveted by everyone who works. Job satisfaction can concretely affect the productivity it provides to the company [5]. Satisfaction at work can provide enthusiasm for work, productivity, and maintain loyalty to continue working in the company. The aspects that lead to job satisfaction are how a job has an appeal to be done and completed, the rewards obtained are based on the results/efforts of the work done, the opportunity for employees to advance in the organization, the supervisor's ability to provide technical assistance and behavioral support and have cooperative co-workers. Job satisfaction is an employee's attitude towards work related to work situations, cooperation between employees, rewards received at work, and matters relating to physical and psychological factors [6]. This definition cannot be interpreted as a single concept. A person can be relatively satisfied with one aspect of his job and dissatisfied with one or more other aspects. The higher the job satisfaction felt by the employees of a company, the stronger the impact on the work productivity of the company's employees [7].

Dessler argues that Quality of Work Life is an effort made by the company to create opportunities for employees to participate in decision making, a conducive work environment, a satisfactory compensation system so that employees can effectively achieve their productivity [8]. Quality of Work Life harmonizes the relationship between workers and the company [9]. Aspects in the quality of work life include being able to make members in it able to participate optimally, not only creating feelings of being accepted, recognized, and appreciated but also providing opportunities to convey ideas, creativity, innovation, suggestions, opinions and criticisms, the company being able to establish employee health centers, organize health care programs, recreation programs and counseling programs for employees, and provide work safety guarantees for employees will create a comfortable feeling for employees in the organization. The company strives so that every resource it has can be used effectively and efficiently so that in the end the company benefits and can improve the company's competitive ability. One of the efforts made by the company is the Quality of Work Life program for employees, where this program focuses on creating a humane working environment. Quality of Work Life (QWL) has a positive and negative impact on the company. The direct positive effect is increasing job satisfaction and commitment, increasing productivity, and increasing organizational effectiveness. While the direct negative influence lies in the level of education of employees, the demands on the organization are also higher, so that it will indirectly be related to commitment to the organization.

Trust in the ability to do something is something that employees need. This is because employees who have selfefficacy will have the confidence to do a good job so that their potential can be channeled optimally [10]. According to Mahmudi and Suroso, self-efficacy relates to a person's 
ability to complete a job or task within the targeted time and the desired standard of work results [11]. In an effort to achieve a goal, employees basically must be equipped with self-efficacy. Self-efficacy is a feeling of confidence in one's own ability to complete tasks and/or problems in various situations. Self-efficacy can affect a person's mindset because with a feeling of self-confidence, employees will try to do the given task with high motivation, calm, and responsible for the results done. The self-efficacy of each individual is different from each others, this is based on three self-efficacy levels. This dimension relates to the degree of difficulty of the task when the individual feels capable of doing it. This dimension has implications for the choice of behavior to be tried or avoided, Strength. This dimension relates to the level of strength of the individual's beliefs or expectations about his abilities. This dimension is directly related to the level dimension, namely the higher the level of difficulty of the task, the weaker the perceived confidence to complete it, Generality. This dimension relates to the area of behavior in which individuals feel confident in their abilities and how a person is able to generalize tasks and previous experiences when facing a task or job, for example, whether he can make the experience as an obstacle or as a failure.

Job satisfaction is thought to be able to increase employee productivity at work. High job satisfaction will make employees loyal to the company so that it will provide better performance from day-to-day. Job satisfaction will create motivation to work better so that productivity will increase [12].

The quality of work life created by the company will increase productivity because the wants and needs of employees have been met by the company. In the end, good quality of work life can increase passion in work so as to increase employee productivity [13].

Self-efficacy in employees such as working to complete their work on time, being able to manage the time to complete the specified work, setting work goals, preparing things in advance at work, always trying to complete work, being creative in various ways, learning from the past from own experience. and others, motivate himself to always be better and not easily attacked by stress.

\section{METHODS}

This study uses a quantitative approach because the data analyzed is in the form of numbers obtained from respondents' answers. The instrument used to obtain the data is a questionnaire consisting of a list of statements with answers arranged on a Likert scale.

Measurement of job satisfaction uses several indicators, namely work according to educational background, work as a learning tool, satisfied with monthly salary, satisfied with allowances, fair promotion policy, promotion policy based on achievement, concern for employees, listening to employees' opinions, cooperative co-workers and colleagues work supports work.

The measurement of the quality of work life uses several indicators, namely, employees are free to convey ideas, employees are involved in the decision-making process, work as a career, job training, medical benefits, counseling programs, retirement programs, and insurance programs.
The measurement of self-efficacy uses several indicators, namely having confidence in the ability to complete work, having confidence in the ability to overcome obstacles, having confidence in self-potential, having the spirit not to give up easily, being able to address problems positively, and using experience to complete work.

Work productivity uses several indicators, namely ability to work, professionalism in work, improving the quality of work, trying new work methods, being on time, enthusiastic in meetings, happy to get difficult jobs, likes to read banking journals, thoroughness in work, trying to give the best results.

The population analyzed was employees of PT Bank Woori Saudara Indonesia 1906 Sub-Branch Kebon Jeruk as many as 57 employees. The number of samples analyzed is the same as the research population. Data were analyzed using PLS with the second-order CFA method. The purpose of PLS is to find the optimal predictive linear relationship in the data. Although PLS can also be used to confirm the theory. But it can also be used to explain whether or not there is a relationship between latent variables. As stated by World in Ghozali Partial Least Square (PLS) is a powerful analytical method, therefore it is not based on many assumptions, so the data does not have to be normally distributed multivariate and the sample does not have to be correct [14].

\section{RESULT}

The data collection process was carried out through a research questionnaire instrument which was distributed to 57 respondents. After distributing the questionnaires, it is known that the questionnaires distributed to the research respondents were 57 and did not experience a reduction when the questionnaire was returned.

In the descriptive analysis of respondents, it is known that as many as $53 \%$ of female employees are due to banking companies more needed employees who are able to serve customers well and have an attractive appearance. Respondents aged 21-30 years dominated by $47 \%$, indicating that PT Bank Woori Saudara Indonesia 1906 Sub-Branch Kebon Jeruk has young employees or fresh graduates. Respondents with a bachelor's degree education dominated by $58 \%$ indicating that employees of PT Bank Woori Saudara Indonesia 1906 Sub-Branch Kebon Jeruk have a good educational background. Employees with income <Rp. $5,000,000$ dominates at $49 \%$, which indicates that the employees of PT Bank Woori Saudara Indonesia 1906 SubBranch Kebon Jeruk do not yet have a good income.

At the variable descriptive stage, it was concluded that PT Bank Woori Saudara Indonesia 1906 Sub-Branch Kebon Jeruk should pay attention to the compensation policy given to employees, employees of PT Bank Woori Saudara Indonesia 1906 Sub-Branch Kebon Jeruk had no commitment to the company, employees must have confidence to overcome obstacles in their work, and employees must show enthusiasm and participation at company meetings.

At the variable descriptive stage, it was concluded that the employees of PT Bank Woori Saudara Indonesia 1906 SubBranch Kebon Jeruk were satisfied because they worked according to their educational background, employees were satisfied because the company provided counseling services for employees, employees had confidence in completing the 
work, and employees had tried to provide the best results for the company. To prove the research hypothesis, testing using the bootstrapping method was carried out on the research model as follows.

TABLE II: HYPOTHESIS TEST RESULT

\begin{tabular}{cccc}
\hline & $\begin{array}{c}\text { Original } \\
\text { Sample }(\mathrm{O})\end{array}$ & $\begin{array}{c}\text { T Statistics } \\
(|\mathrm{O} / \mathrm{STDEV}|)\end{array}$ & P-Values \\
\hline $\begin{array}{c}\text { Job Satisfaction- > } \\
\text { Employee Work Productivity } \\
\text { Quality of Work Life- > } \\
\text { Employee Work Productivity } \\
\begin{array}{c}\text { Self-Efficacy -> Employee } \\
\text { Work Productivity }\end{array}\end{array}$ & 0.406 & 4.532 & 0.000 \\
\hline
\end{tabular}

The original sample value has a positive direction of 0.406 with a significant 4.532 above the standard 1.96. This shows that if job satisfaction is getting better, then employee productivity will increase. The original sample value has a positive direction of 0.528 with a significant 6386 above the standard 1.96. This shows that if the Quality of Work Life is getting better, then Employee Productivity will increase. The original sample value has a positive direction of 0.361 and is significant at 2,931 above the standard 1.96. This shows that if Self Efficacy is getting better, then Employee Productivity will increase.

\section{DISCUSSION}

Job satisfaction is proven to significantly increase work productivity. Based on the results of descriptive analysis, it is known that employees are satisfied because they work according to their educational background. This is very important because the employees of PT Bank Woori Saudara Indonesia 1906 Sub-Branch Kebon Jeruk did not take long to adapt to work operations at the Bank. When employees work according to their educational background, the adaptation process required is not too much. Adapting to the office environment, office friends and superiors is quite easy to do, but adapting to work is difficult because there are several terms in banking or finance that will be difficult to understand if you do not have a financial or banking education background. With the right educational background, employees will have the insight and competence to continuously improve their work productivity. The implication of this research is that the Human Resource Department (HRD) division prioritizes employees with a financial or banking education background so that employees can quickly master the work and work procedures at PT Bank Woori Saudara Indonesia 1906. The results of this study are supported by previous research [15], [16].

Quality of work life is proven to increase work productivity. The results of this study imply that the better the quality of work life felt by the employees of PT Bank Woori Saudara Indonesia 1906 Sub-Branch of Kebon Jeruk, the higher the work productivity of employees. Based on the results of descriptive analysis, it is known that the existence of counseling services is important for employees of PT Bank Woori Saudara Indonesia 1906 Sub-Branch Kebon Jeruk. Through counseling services, employees will find it easier to understand themselves and can continue to be able to find solutions to any problems faced both at the Bank and at home so that employees will be more focused when working. With the Covid-19 pandemic, counseling services provided by the company are very important so that employees of PT Bank Woori Saudara Indonesia can more easily reduce stress at work so that employee productivity at work can increase. The implication of this research is that the Human Resource Department (HRD) division continues to provide counseling services to employees, both offline and online through the Employee Assistance Program (EAP) which is conducted more regularly. The results of the study are supported by previous studies [17], [18].

Self-Efficacy is proven to increase productivity. The results of this study imply that the better the self-efficacy of the employees of PT Bank Woori Saudara Indonesia 1906, the Kebon Jeruk Sub-Branch, the higher the work productivity of employees. Based on the results of descriptive analysis, it is known that confidence in the ability of employees to complete work is important for employees to increase their productivity. Various challenges faced at work can make employees doubt their competence in completing work. Therefore, superiors at PT Bank Woori Saudara Indonesia 1906 Sub-Branch Kebon Jeruk need to provide guidance to employees to bring out the best competencies they have so that they can continue to be able to increase their productivity. The implication of this research is that the leadership at PT Bank Woori Saudara Indonesia 1906 Kebon Jeruk Sub-Branch regularly conducts sharing sessions every time they start work in the morning. It is intended to evaluate employee performance and help employees to resolve obstacles in their work. The results of the study are supported by previous research [19], [20].

\section{CONCLUSION}

The results of the analysis prove that the better the job satisfaction felt by the employees of PT Bank Woori Saudara Indonesia 1906 Sub-Branch Kebon Jeruk, the productivity of employees will increase, the better the Quality of Work Life felt by the employees of PT Bank Woori Saudara Indonesia 1906 Sub-Branch Kebon Jeruk, the productivity of employees will increase. increases, and the better the selfefficacy of the employees of PT Bank Woori Saudara Indonesia 1906 Sub-Branch Kebon Jeruk, the productivity of employees will increase.

It is recommended that the management of PT Bank Woori Saudara Indonesia 1906 Sub-Branch Kebon Jeruk review the salary policy given to employees. What can be done is to apply merit pay, which is a compensation system based on employee performance. So, the better the employee's performance for the company, the greater the nominal amount of compensation that will be given.

It is recommended that the management of PT Bank Woori Saudara Indonesia 1906 Kebon Jeruk Sub-Branch conduct an assessment to provide an objective promotion and involve the assessment of all employees at the Bank's Branch Office for a certain period. Therefore, every employee has the same right to occupy a better position so that employees have certainty about a career at PT Bank Woori Saudara Indonesia 1906. 
It is recommended that the management of PT Bank Woori Saudara Indonesia 1906 Sub-Branch Kebon Jeruk consistently conduct sharing sessions of knowledge transfer between employees so that employees help each other to solve obstacles in their work.

\section{LIMITATION}

This research is limited to the analysis of employees of PT Bank Woori Saudara Indonesia 1906 Sub-Branch of Kebon Jeruk so it cannot represent the productivity of employees in the company as a whole. In addition, this research is only limited to job satisfaction, quality of work life and selfefficacy in its analysis of work productivity.

\section{REFERENCES}

[1] Riniwati, H. 2016. Manajemen Sumber Daya Manusia, Edisi 1, Malang: UB. Press.

[2] Muhammad. 2015. Manajemen Dana Bank Syariah, Jakarta: PT. Raja Grafindo Persada.

[3] Sinungan, M. 2014. Produktivitas: Apa dan Bagaimana, Jakarta: Bumi Aksara.

[4] Mathis, R. L., \& Jackson. 2012. Manajemen Sumber Daya Manusia, Jakarta: Salemba Empat.

[5] Handoko, T. H. 2015. Manajemen, Edisi Kedua, Yogyakarta: BPFE.

[6] Sutrisno, E. 2016. Manajemen Sumber Daya Manusia, Jakarta: Kencana Prenada Media Group.

[7] Saprudin, \& Koeswardhana, G. 2018. Pengaruh Kepuasan Kerja dan Pelatihan terhadap Produktivitas Kerja Karyawan. Journal of Information System, Applied, Management, Accounting and Research, 2(4): 14-19.

[8] Dessler, G. 2017. Manajemen Personalia, Jakarta: Erlangga.

[9] Wibowo. 2016. Manajemen Kinerja, Jakarta: PT Raja Grafindo Persada.

[10] Feist, J., \& Feist, G. 2011. Teori Kepribadian, Jakarta: Salemba Humanika.

[11] Mahmudi, M. H., \& Suroso, S. 2014. Efikasi Diri, Dukungan Sosial dan Penyesuaian Diri Dalam Belajar. Persona, Jurnal Psikologi Indonesia, 3(2): 183-194.

[12] Luturmas, J. R. 2017. Pengaruh Budaya Kerja Dan Kepuasan Kerja Trhadap Produktivitas Kerja Karyawan Ajb Bumiputera 1912 Cabang Ambon. Jurnal Penelitian Manajemen Terapan (PENATARAN), 2(2): $153-163$.

[13] Muryadi, M. A. 2018. Pengaruh Kualitas Kehidupan Kerja (QWL) Dan Penghargaan Terhadap Produktivitas Guru SD Negeri Di Kecamatan Kebon Jeruk Jakarta Barat. Manajemen Pendidikan, 9(1): 71-80.

[14] Ghozali, I. 2014. Structural Equation Modeling, Metode Alternatif dengan Partial Least Square (PLS), Semarang: Badan Penerbit Universitas Diponegoro.

[15] Hoboubi, N., Choobineh, A., Kamari Ghanavati, F., Keshavarzi, S., \& Akbar Hosseini, A. 2017. The Impact of Job Stress and Job Satisfaction on Workforce Productivity in an Iranian Petrochemical Industry. Safety and Health at Work, 8(1): 67-71.

[16] Embuldeniya, A. 2018. Multidisciplinary. EPRA International Journal of Multidisciplinary Research, 3(12): 14-23.

[17] Horst, D. J., Broday, E. E., Bondarick, R., Filippe Serpe, L., \& Pilatti, A. (2014). Quality of Working Life and Productivity: An Overview of the Conceptual Framework. International Journal of Managerial Studies and Research, 2(87): 324-330.

[18] Tilaar, N., Sendow, G., \& Jorie, R. (2017). Pengaruh Kualitas Kehidupan Kerja, Disiplin Kerja Dan Kompensasi Terhadap Produktivitas Kerja Pegawai Pada Kantor Dinas Lingkungan Hidup Provinsi Sulawesi Utara. Pengaruh Kualitas Kehidupan Kerja, Disiplin Kerja Dan Kompensasi Terhadap Produktivitas Kerja Pegawai Pada Kantor Dinas Lingkungan Hidup Provinsi Sulawesi Utara, 5(2): 2070 2078.

[19] Li, Y., Zhang, J., Wang, S., \& Guo, S. (2019). The effect of presenteeism on productivity loss in nurses: The mediation of health and the moderation of general self-efficacy. Frontiers in Psychology, 10(1745): 1-11.

[20] Black, J., Kim, K., Rhee, S., Wang, K., \& Sakchutchawan, S. (2019). Self-efficacy and emotional intelligence: Influencing team cohesion to enhance team performance. Team Performance Management, 25(1-2): $100-119$. 